\title{
Weathering traces in ancient bricks from historic buildings
}

\author{
P. Lopez-Arce ${ }^{a}, *$ J. Garcia-Guinea \\ ${ }^{a}$ Centro Tecnológico de Materiales (AITEMIN), C/ Rio Cabriel, s/n, 45007 Toledo, Spain. \\ ${ }^{b}$ Museo Nacional de Ciencias Naturales (CSIC), C/ Jose Gutierrez Abascal 2, 28006 Madrid, Spain.
}

(*) Corresponding author: paulal.arce@aitemin.es

\begin{abstract}
The aim of this work was to determine the type of weathering suffered by bricks belonging to a number of historic buildings in Toledo, Spain. These bricks had been exposed to either aerial or burial environments, came from different places in the selected buildings, were of different mineralogical composition, and had been fired at different temperatures. X-ray diffraction, scanning electron microscopy and the analysis of their physical properties showed the best conserved to be those that had been buried. Buried Roman bricks made from noncalcareous materials fired at $>900^{\circ} \mathrm{C}$ and with a vitrified matrix showed few signs of weathering. Buried Islamic and Mudejar-Romanesque bricks made from calcareous clays and fired at temperatures of $<800^{\circ} \mathrm{C}$ were similarly well conserved. These showed calcareous cementation of their pore systems, which improved their physical properties. Bricks from the external and internal walls of buildings (e.g., Islamic-Mudejar and Romanesque bricks from inner courtyards and cellars) that had been exposed to aerial conditions were less well conserved. These were made from calcareous materials and had been fired at high temperatures $\left(>900^{\circ} \mathrm{C}\right)$. They showed a number of weathering traces but overall were still in relatively good condition. The worst conserved of all were neoclassical bricks from upper
\end{abstract}


storey internal walls. These were made of calcareous material and had been fired at temperatures of between 800 and $900^{\circ} \mathrm{C}$.

The mineralogical composition of the raw materials, the firing temperature, the location of the bricks in the buildings, the environments to which they had been exposed, the action of natural or polluted filtration water, the action of microorganisms and the reigning environmental conditions, all contributed towards the state of conservation of the bricks. Such knowledge may help in the choice of appropriate cleaning or restoration treatments for architectural heritage of brick construction.

Keywords: Heritage, Historical buildings; Bricks; Physical, Chemical and Biological Weathering.

\section{Introduction}

In geological terms, a brick can be defined as a metamorphic rock that is stable only under the final conditions of pressure and temperature of its artificial firing. When exposed to sub-aerial conditions (as part of a building) or to burial environments, bricks become exposed to very different temperatures, pressures and moisture regimes, as well as to the actions of aqueous solutions, atmospheric gases and organisms. Under these conditions they become unstable and suffer micro-structural and mineralogical changes known as weathering or deterioration. This causes the mineralogical breakdown of their crystalline lattices, allowing ionic migration to produce new minerals with a tendency to enter thermodynamic equilibrium with their environment. Rock deterioration can be physical, via the disaggregating mechanisms of frost and salt weathering, or chemical, via reactions between the rock surface and the atmosphere (when exposed to the air), the soil (in burial environments), or dissolved ions (when exposed to water). Mineral decomposition produces new phases following processes such as: (i) 
changes in self-energies through structural phase-transition, (ii) loss of coherency in microtwinning and ex-solution interfaces in mixed phases (e.g., alkali feldspars), (iii) alkali-proton exchange at mineral surfaces and acid drainage of alkalis, (iv) the chemical sulphating of calcium-bearing surfaces, and (v) crystallization of neo-formed phases via the interaction between fluids and minerals (calcite, sulphates, phyllo-silicates, iron oxo-hydroxides). Biological weathering occurs concurrently with physical and chemical weathering; in fact it can be described as physical and chemical weathering caused by biological agents [1-2]. The characterization of weathering traces in ancient bricks from historical buildings is a crucial task when conservation activities or cleaning treatments are planned. To avoid any further deterioration, appropriate surface cleaning machines and products must be chosen, appropriate for the specific chemical properties of the material to be treated. Cleaning treatments are chosen according to their method of action, e.g., the following have been used to remove black gypsum dendrite crusts: (i) sepiolite, because of its solvent action, (ii) ammonium bicarbonate, because of its exchange action, (iii) EDTA, because of its chelating action, (iv) hydrogen peroxide, because of its toxic action on organisms, and (v) nylon brushes, because of their abrasive action [3].

The high level of air pollution near industrial sites leads to significant increases in the deterioration rates of buildings, engineering structures and historical monuments. Burning fossil fuels increases the concentration of $\mathrm{NO}_{\mathrm{x}}$ and $\mathrm{SO}_{2}$ in the atmosphere - the agents most harmful to masonry [4]. The factors influencing the oxidation of sulphite to sulphate include the type and porosity of the stone under attack, the moisture level, the nature of the oxidizing agents involved and the presence of extraneous reactants, e.g. metal oxides, chlorine and ammonium salts [5]. The sulphuric acid generated by the catalytic oxidation and hydrolysis of $\mathrm{SO}_{2}$ attacks carbonates and Ca-rich, high-temperature silicates such as wollastonite, gehlenite and Ca-feldspars, resulting in the formation of gypsum crystals [6]. Sulphating can proceed in 
two ways: (i) $\mathrm{SO}_{2}$ can be adsorbed onto the stone where it reacts with calcium carbonate and water to form calcium sulphite, which is then further oxidised to gypsum, or (b) it can be transformed into $\mathrm{H}_{2} \mathrm{SO}_{4}$ either directly on the stone or in the air, the subsequent attack on the carbonate leading to the formation of gypsum crust [7].

With respect to other pollutants, baked bricks can be used as geochemical monitors of heavy metal fallout. Analysing samples of different ages collected from old monuments can reveal the recent history of heavy metal pollution $[8,9]$.

Micro-organisms influence brick weathering in a number of ways: (i) via the decomposition of organic matter, from which many elements, organic acids and $\mathrm{CO}_{2}$ are mobilized, (ii) by directly decomposing minerals (by exuding metabolically-produced organic acids and releasing enzymes that enhance chemical reactions), (iii) by putting strain on cavities and fissures, (iv) by giving rise to chemical weathering, and (v) by taking part directly in the crystallization process (bacteria can precipitate calcite and other minerals). Many bacilli form calcite crystals on solid media that contain sodium acetate $[10,11]$. Bacterial action may facilitate brick decay through the consumption of chemical compounds in the stone and via their metabolic products [3]. It is reported that spherulite and polycrystalline aggregates of calcite are produced by the activity of Escherichia coli in a gel medium; metabolic products such as $\mathrm{CO}_{2}$ and $\mathrm{H}_{2} \mathrm{O}$ form from polysaccharides, and with calcium ions form carbonic acid, leading to a crystalline deposit [12]. The colonization of buildings by lichens has been studied in churches and granite monuments $[13,14]$. Lichens can, in some instances, protect exposed brick surfaces from atmospheric weathering, reducing the losses of mobile elements. They can also prevent grain disaggregation since their thalli (frequently accompanied by bacteria, cyanobacteria, algae and fungi) retain water, increasing the wetting period and avoiding salt crystallization. However, they can also be destructive [1]. Micro-organisms can form biofilms on stone surfaces or at the lichen-rock interface. These play an important role in the 
biodeterioration of stone monuments [15] by exuding acids that break down rock-forming minerals (leading to etching and disaggregation). Lichens also expand and contract with changes in moisture levels, and thereby effect mechanical damage through the loss of rock fragments.

Manganese micro-nodules (around $2 \mu \mathrm{m}$ in diameter) have been found growing under the external biofilm surface of buried bricks. SEM studies have shown that biofilms precipitate these micro-nodules on ancient brick surfaces, possibly through the imbibing of aqueous solutions rich in anthropogenic $\mathrm{MnO}_{4} \mathrm{~K}$ in a reducing environment, or through the oxidation of $\mathrm{Mn}^{2+}[16]$.

Weathering processes occur in open systems in non-equilibrium conditions. Although the mechanisms can be studied separately, the physical, chemical and biotic reactions involved proceed concurrently. The aims of this work were to study and classify the different types of weathering in ancient bricks from historical buildings of Toledo, Spain, and to relate these findings to their state of conservation.

\section{Materials and Methods}

The experimental material included 15 brick samples from the historic buildings of Toledo, Spain. These were first classified according to whether they had been exposed to a burial (I) or an aerial (II) environment. Those from aerial environments were sub-classified according to their specific location in the building: (A) outdoor walls, (B) indoor walls. Finally, the outdoor wall samples were classified as belonging to building facades $\left(\mathrm{A}_{1}\right)$ or inner courtyards $\left(A_{2}\right)$, and the indoor wall samples as belonging to cellars or basements $\left(B_{1}\right)$ or upper floors $\left(B_{2}\right)$. Table 1 shows the buildings from which the samples were taken, and the estimated age of the bricks according to architectonic style and period. Table 2 shows the original locations, positions and architectonic structures for the samples exposed to aerial environments. Table 3 shows similar information for the samples exposed to burial environments. 
Brick mineralogy was determined by X-ray diffraction (XRD) using a Phillips PW-1710 powder diffractometer with a $\mathrm{CuK} \alpha$ radiation source. Patterns were obtained by step scanning from $3^{\circ}$ to $75^{\circ} 2 \theta$ with a count of $0.5 \mathrm{~s}$ per step. The exploration speed was $7^{\circ} / \mathrm{min}$; the X-ray tube settings were $40 \mathrm{kV}$ and $40 \mathrm{~mA}$. Scanning electron microscopy with energy-dispersive X-ray analysis (SEM-EDS) was used to study the morphology and chemical composition of the weathering traces. For this, brick surfaces were coated with gold $(20 \mathrm{~nm})$ in a Bio-Rad SC515 sputter coating apparatus. General SEM observations were made using a Philips XL20 SEM at acceleration voltages of 20-30 kV. Energy dispersive analyses were performed using a Philips EDAX PV9900 apparatus equipped with an ECON light element detector. Physical properties were determined according to UNE-EN quality standards tests: density according to standard 772-3:1999, water absorption percentage according to standard 67027:1984, and suction percentage according to standard 67031:1985-1986. Strength compression measurements were made according to UNE standard 67026/1M:1995 EX, using an Ibertest 1500 press. The load velocity was $8.5 \mathrm{kN} / \mathrm{s}$. Finally, porosity was determined by mercury intrusion porosimetry using a Micromeritics Autopore III S.9400 apparatus.

The bricks were re-fired to help determine their original firing temperature according to the method of López Arce et al. [17].

\section{Results and Discussion}

The studied bricks had similar mineralogical compositions; quartz and feldspar were found in all samples. Mineral phases not present in all samples included calcite, illite, gehlenite and diopside. Dolomite and hematite were found (separately) in only two samples (Fig 1). The mineralogical composition of the bricks was determined in order to estimate their original firing temperatures: X-ray diffraction analysis and re-firing [17] at different temperatures can help estimate the original firing temperature via the development or disappearance of different 
mineral phases. The presence of primary dolomite and calcite suggest low firing temperatures (e.g., $<800^{\circ} \mathrm{C}$ ) since these minerals decompose at around $750^{\circ} \mathrm{C}$ and $800^{\circ} \mathrm{C}$ respectively. The existence of neo-formed mineral phases, such as gehlenite and diopside (formed from calcite and dolomite and their reaction with silicates during firing) indicates firing temperatures above $900^{\circ} \mathrm{C}$ (or above $800^{\circ} \mathrm{C}$ if only gehlenite is present). The sampled bricks fell into different categories: (i) those fired at well over $900^{\circ} \mathrm{C}$, which had no illite but did have gehlenite and diopside (samples CDO, CG1, COR and SCL); (ii) those fired at just over $900^{\circ} \mathrm{C}$, with illite, gehlenite and diopside (SEM, CG2); (iii) those fired at just below $900^{\circ} \mathrm{C}$, with gehlenite, illite, hematite but no diopside (DIP); (iv) those fired at well over $800^{\circ} \mathrm{C}$, without diopside but with gehlenite, illite, and either with or without primary or secondary calcite but without primary dolomite (FAT, CG3 and AL1); (v) those fired below $800^{\circ} \mathrm{C}$, without neo-formed alumino-silicates (gehlenite and diopside) but with illite and primary or secondary calcite and dolomite (AL2 and AL3) (calcite and dolomite cannot be used as firing temperature indicators without prior identification of their primary or secondary origin; the gehlenite traces in AL3 may have been caused by calcite modification during burial by the interaction of water with humic acids [18]); and (vi) samples fired at around $900^{\circ} \mathrm{C}$, without gehlenite (RFA, CAB and CAH), the original composition of which cannot have contained calcite. The presence of diopside was used to assign a firing temperature of well over $900^{\circ} \mathrm{C}$ for sample $\mathrm{CAH}$ which contained diopside but no illite, of just over $900^{\circ} \mathrm{C}$ for sample RFA which contained diopside, illite and hematite, and of just under $900^{\circ} \mathrm{C}$ for $\mathrm{CAB}$ which had diopside but no illite.

Table 1 shows the appearance, colour and texture of the bricks, while Table 4 shows their mineralogical composition and estimated firing temperatures. Three general groups of bricks were established according to these characteristics: (i) fine textured, light salmon pink and creamy-white coloured bricks fired at high temperatures; (ii) medium and small grained, pale reddish, salmon orange and brown bricks fired at medium to low temperatures, and (iii) 
coarse and medium grained, orange, red and brown bricks fired at medium or high temperatures. The estimate of the original firing temperature of the bricks, determined by mineral paragenesis analysis, was compared with their conservation status (determined from their physical properties).

SEM-EDS analysis revealed the types and morphology of the weathering trace on the surface and inside the bricks, as well as their chemistry. The weathering mechanisms affecting the bricks were classified as follows: (i) physical weathering in the strict sense, such as fissures, fractures and de-cohesion (samples SEM, AL2, CG1 and SCL); (ii) chemical weathering such as corrosion-dissolution processes giving rise to re-crystallizations; and (iii) biological weathering - the presence of organisms, organic deposits and bio-precipitated minerals. The three types of weathering are caused by the interaction of aqueous solutions with organic and inorganic deposits and with the original minerals of the bricks. Table 5 shows the different types of weathering traces found in the samples (observed mainly in SEM analyses). Figure 2 shows SEM images of traces of physical and chemical weathering, such as the presence of fissures on the surface of sample CG1 (Fig. 2a) and the corrosion-dissolution of calcite crystals in samples COR and AL2 (Fig. 2b and 2c respectively). The inside of sample AL3 showed complex traces of corrosion and dissolution processes, giving rise to mineral reprecipitation (where tabular and elongated calcite crystals re-crystallized) (Fig. 2d). Aqueous solutions infiltrated the brick through its pore system, dissolving organic deposits, the original minerals, and late inorganic deposits of anthropogenic origin (such as atmospheric pollutants, gases from vehicles, central heating and factories, and fluid sludge with heavy metals).

Such corrosion and dissolution processes caused by aqueous solutions led to the precipitation of new minerals both inside and outside the studied bricks. A good example is the gypsum produced by the reaction between sulphur dioxide and carbonates and Ca-rich high-temperature silicates such as gehlenite and Ca-feldspars. Sulphur dioxide is very reactive and corrosive and 
changes into sulphuric acid in the presence of water and oxidising agents. Sample COR (from an internal wall exposed to an aerial environment) showed precipitates of neo-formed gypsum. Gypsum precipitations can also be formed from the dissolution of the lime in mortar, as seen in samples, SEM, CG2, SCL, RFA and CAB.

Particles can also be deposited by associations of lichen and algae, diatoms, fungal mycelia and different types of spore etc. Figure 3 shows spores from fungi on the surface of sample COR, and a bacterial colony covering the surface of sample AL3 (Fig. 3a and $3 \mathrm{~b}$ respectively). These biological deposits are also important in the late neo-formation of minerals, in which pollutants are involved. Aqueous solutions interact with them, as well as with the minerals both inside the bricks and on their surfaces. Bio-films were also observed covering some brick surfaces; the interaction between these green layers and additional aqueous solutions, plus the dissolution of the original grain minerals, precipitated manganese micro-nodules in bricks exposed to burial environments. Figure 3c shows these Mn nodules in AL1 bricks, formed either by the action of reducing agents on aqueous solutions rich in anthropogenic $\mathrm{MnO}_{4} \mathrm{~K}$ or by oxidation mechanisms linked to the algae-lichen biofilm. Chemical analyses of the water of Toledo have shown it can have a high algal biomass and high levels of manganese [16]. The Mn nodules in sample AL1 showed a reticulated structure composed of micro-needles (Fig. 3c). These spherulite shapes are very similar to the reticulated structures obtained in the laboratory with Marinococcus halophilus strains at a salt concentration of $20 \%$ [19]. This suggests that bacteria interacted with the lichen-algae association to precipitate these nodules. From morphological evidence and the sequential processes of carbonate biolith formation [20, 21], bioliths are formed by the progressive union of calcified bacterial bodies initially giving rise to porous, relatively unstructured forms. These then undergo internal re-crystallization before finally forming compact, fibrous, radiate spherulites. The formation of spherules with morphology similar to an algal cell in division (Fig. 3d) suggests that the calcite crystals found in sample CG1 were 
precipitated by the interaction of algae with carbonates from the brick surface or by carbonated solutions.

In accordance with the SEM analyses and the weathering traces listed in Table 5 (recompiled in Table 7), the samples with the largest number of weathering traces were those from burial environments (except Roman samples CAH and RFA, which have no carbonates). The samples exposed to aerial environments showed the following weathering traces:

\section{(A) Outdoor walls:}

$\left(\mathrm{A}_{1}\right)$ bricks from facades e.g., sample $\mathrm{COR}$, showed many traces of weathering, mainly surface re-crystallizations (gypsum, $\mathrm{NaCl}$ ) and some organic deposits (spores).

$\left(\mathrm{A}_{2}\right)$ bricks from inner courtyards, e.g., sample DIP, showed scant weathering traces, for example organic deposits (fungi hyphae) and some corrosion. Sample SME showed mild signs of weathering such as fissures, internal calcite re-crystallization and organic deposits.

\section{(B) Indoor walls:}

$\left(B_{1}\right)$ bricks from cellars or basements, e.g., samples CG1, CG2 and CG3, showed few traces of weathering, mainly dissolution and re-crystallization processes (salts, calcite). Abundant organic deposits (hyphae) were seen in sample CG1.

$\left(\mathrm{B}_{2}\right)$ bricks from upper floors, e.g., samples FAT and CDO, showed little to mild weathering respectively, mainly microorganisms and organic deposits (bacteria, hyphae), some dissolution process, surface re-crystallizations (calcite) and bio-crystallization.

The frequent association of lichen and bacteria with traces of dissolution suggests they are involved in this process, which leads to organic and inorganic re-crystallization. Lichens have an important influence on the deterioration processes of surface layers, which suffer the direct chemical attack of their thalli [22]. The dissolution of minerals by lichens was observed both at the brick surface and in the internal mortar, producing traces such as micropitting and calcite crystal etching in areas in contact with the hyphal bundle. Calcite-bearing bacteria can 
also decrease the amount of water absorbed by bricks, the production of new calcite crystals being reduced by about $50 \%$. Porosity is also reduced by the presence of large amounts of biological matter, which physically hinder water movements [23].

In bricks, large numbers of weathering traces do not necessarily mean a poorer conservation status; weathering processes can in fact improve surface strength. A thick white crust, produced by weathering can be impermeable and rich in calcite, and the pores of the bricks can be filled with carbonated cement. This can lead to a $30 \%$ reduction in porosity and render a greater surface strength and lower water absorption than that of calcareous rock. This type of crust can form a protective layer on limestone surfaces [24].

The physical properties of ancient bricks are indicators of their conservation status. Close relationships are seen between the latter and (i) the mineralogy of the bricks and their original firing temperature, (ii) the age of the bricks, (iii) the environment to which they were exposed (aerial or burial), (iv) the location and position of the bricks in their buildings (for air-exposed samples), and (v) the presence of physical, chemical and biological weathering traces.

Petrophysical values such as high compression strength, low porosity, and low water absorption and suction percentages are good indicators of the conservation status of a brick. The non-calcareous sample $\mathrm{CAB}$ showed medium compression strength, low porosity, and low water absorption and suction percentages. Samples COR and CG2 showed high compression strengths, high porosity, and high water absorption and suction percentages. These differences might be explained by the porosity that developed during the high temperature firing conditions used in the manufacture of the calcareous bricks COR and CG2. Mean pore size may be related to the firing temperature, with a large pore size found in samples fired above the degasification temperature for carbonates (around $850^{\circ} \mathrm{C}$ ) but below the melting point of the brick (about $1000^{\circ} \mathrm{C}$ ), at which the pores become filled with glass. Porosity and mean pore diameter are variables that can be modified by weathering processes 
after firing. Post-firing variation of the pore size is due to late cementation via dissolution and re-precipitation mechanisms.

Taking into account the physical properties of the bricks (Tables 4 and 6), the type of environmental exposure they suffered (Tables 2 and 3), their mineralogy and firing temperatures, and their ages and weathering traces (Table 7), the following conclusions can be drawn:

\section{-1. Buried samples:}

-1.1 Roman bricks CAH and RFA, with very high and high compression strength, respectively, very low water absorption and suction percentages, and medium-high porosity (mean diameter pore) were the best preserved Roman bricks in this type of environment. These were the oldest samples but they had been subjected to very high firing temperatures. The raw materials used in their composition were non-calcareous and overall they showed few traces of weathering. This might be explained by their very high temperature firing and the lack of calcite in the raw material; they had no gehlenite and possessed a vitrified matrix which hinders dissolution, corrosion and re-crystallization processes.

-1.2. The Romanesque-Mudejar samples AL2 and AL3 showed high compression strength, and medium to low water absorption and suction percentages and porosity. They therefore had a good conservation status despite their low firing temperature and original calcareous composition. However, they showed a large number of weathering traces, including signs of biological action, corrosion, dissolution and re-crystallization. The filling of the pore system with calcite cement during the burial period may have improved their physical properties, increasing their compression strength and reducing their water absorption and suction percentages.

\section{- 2. Aerial samples}


- 2.1. Samples COR, DIP, CG2 and CG3 were relatively young and came from building facades, inner courtyards and cellars. They showed high compression strengths, although less than the samples mentioned above. They also showed high porosity and a high water absorption percentage, and had been produced at high firing temperatures from an original illitic-calcareous material. They showed few traces of weathering and were in a good state of conservation.

-2.2. The youngest samples, SEM, FAT and CG1, which came from inner courtyards, upper floors and cellars respectively, showed medium compression strength, medium water absorption and suction percentages, and low porosity. They were produced at a high firing temperature. Weathering traces were plentiful but sample SME was well conserved. This brick showed medium compression strength, high water absorption and suction percentages, and a very high porosity. Samples FAT and CG1 were fired at medium and high temperatures respectively, and showed moderate and abundant weathering traces respectively. The three samples had an original illitic-calcareous composition.

The worst conserved samples were CDO (aerial) and SCL (buried), both recent samples with an original illitic-calcareous composition. Both showed low compression strengths and very high water absorption percentage, although paradoxically they were made at very high firing temperatures. Sample CDO came from an inside wall (upper floor) and showed moderate weathering traces, surface re-crystallization and some organic deposits. Sample SCL also showed many weathering traces, such as re-crystallization, fissures and big cracks, which explain its very low compression strength. This sample was part of a cellar and was exposed to more moisture and infiltration water than the other buried samples. In the centre of Toledo, buried bricks are generally better protected from environmental variations, and underground micro-organisms and fluids re-precipitate minerals in their pore system, improving their physical properties. Bacteriogenic calcite can solidify a brick artificially, although some 
authors [23] report this calcite can lead to the appearance of new mineral products and bacterial strains with negative consequences. Natural physico-chemical and biological weathering traces, such as re-crystallization in fissures and pore systems, might improve the physical properties via cementation processes. These occur more easily in originally calcareous bricks fired at below $800^{\circ} \mathrm{C}$ (due to the dissolution and re-crystallization of primary calcite) or above $900^{\circ} \mathrm{C}$ (due to the recarbonation of portlandite $\left[\mathrm{Ca}(\mathrm{OH})_{2}\right]$ generated by hydration of $\mathrm{CaO}$, a product of the decomposition of carbonates during firing and their later transformation into secondary calcite).

\section{Conclusions}

Although physico-chemical and biological phenomena inside the pore system of a brick can enlarge fissures and damage the overall structure, weathering processes need not always cause damage: sometimes they improve a brick's physical properties by decreasing its water absorption and suction percentages through cementing, dissolution and re-crystallization processes. The compression strength increases as a result. In the present study, these processes were more common in bricks made of calcareous clays and exposed to burial environments in which the pore system could fill with secondary calcite by re-crystallization. In calcareous bricks fired at below $800^{\circ} \mathrm{C}$, this might occur via the dissolution of primary calcite, or the filtration of calcareous aqueous solutions, followed by the re-crystallization of secondary calcite in the pores and fissures. In calcareous bricks fired at temperatures of over $900^{\circ} \mathrm{C}$, this might occur by portlandite recarbonation. These showed a good state of conservation. The buried samples with an estimated firing temperature of $>900^{\circ} \mathrm{C}$ whose raw material was not carbonated were the best conserved. These showed better physical properties, a vitrified matrix and few weathering traces. The samples fired at medium firing temperatures (i.e., around $800^{\circ} \mathrm{C}$ ) and with an originally calcareous composition were well 
conserved, suggesting that dissolution and re-crystallization processes improved their physical properties. Aerial bricks from facades and inside walls, inner courtyards and cellars, thought to have been produced at high firing temperatures $\left(>900^{\circ} \mathrm{C}\right)$ and which had a calcareous composition, were also well preserved and showed high compression strengths. Samples collected from upper floors, made at firing temperatures of $>800^{\circ} \mathrm{C}$ and of calcareous composition were more poorly conserved.

In addition to the intrinsic physical properties, mineralogical composition and firing temperature of the bricks, weathering also depended on their location in the building, the architectonic stress they suffered, and factors such as natural and anthropogenic infiltrations, exposure to modern-day pollutants, the action of biological colonies and environmental conditions. Weathering traces in bricks need not necessarily imply a poorer state of conservation. While they may not be aesthetically pleasing, weathered bricks may have improved physical properties. SEM analysis can reveal the morphological details of bricks and throw light on the chemistry of their surfaces, which can be of use when making choices concerning cleaning agents and treatments.

\section{Acknowledgements}

The authors are indebted to Josefo Bedoya and Laura Tormo (ESEM-EDS-WDS microscope technicians at the Museo Nacional de Ciencias Naturales, Madrid) for the photomicrographs used in this study. We are also grateful to Juan Manuel Rojas Malo, who helped with sampling and archaeological documentation. We also thank Carlos Sánchez (Faculty of Chemistry Sciences, Ciudad Real) for performing the XRD analyses. Thanks to the biologist and editor Adrian Burton for some corrections made in this article. This work was supported by Spanish project MCYT IFD 1997-0561 and agreement CICYT-JCCM (2002-2004). 


\section{References}

[1] Mottershead D., Gorbushina A., Lucas G., Wright J. The influence of marine salts, aspect and microbes in the weathering of sandstone in two historic structures. Building and Environment, 2003; 38: 1193-1204.

[2] Aires-Barros L. Modes and Mechanisms of rock weathering. In: Protection and Conservation of the Cultural Heritage of the Mediterranean Cities. $5^{\text {th }}$ International Symposium on the Conservation of Monuments in the Mediterranean Basin. Seville, 2000, pp.3-6.

[3] Moropoulou A., Kefalonitou S. Efficiency and countereffects of cleaning treatment on limestone surfaces - investigation on the Corfu Venetian Fortress. Building and Environment, 2002; 37: 1181-1191.

[4] Rozniakowski K., Klemm P., Klemm A.J. Some experimental results of laser beam interaction with surface layer of brick. Building and Environment, 2001; 36: 485-491.

[5] Massey S.W. The effects of ozone and $\mathrm{NO}_{\mathrm{x}}$ on the deterioration of calcareous stone. Science of Total Environment, 1999; 227: 109-121.

[6] Cultrone G, De La Torre MJ, Sebastián EM, Cazalla O, Rodríguez-Navarro C. Behavior of brick samples in aggressive environments. Water, Air, and Soil Pollution, 2000; 119: 191-207.

[7] Sabbioni C. Multipollutants: Evidence in stone and mortar decay. In: Protection and Conservation of the Cultural Heritage of the Mediterranean Cities. $5^{\text {th }}$ International Symposium on the Conservation of Monuments in the Mediterranean Basin. Seville, 2000, pp.15-16. 
[8] Shrivastav R., Mathur S.K., Shrivastav S., Srivastava M.M., Das S., Prakash S. Bricks as historical record of heavy metals fallout: study on copper accumulation in Agra soils since 1910. Environ Mon Ass, 1996; 40:271-278.

[9] Shrivastav R., Mathur S.K., Srivastava M.M., Das S., Prakash S. Bricks reveal recent history of heavy metal pollution in soil around a north Indian city. Science of Total Environment, 1998; 209: 41-46.

[10]Laiz L., Cardell C., Rodriguez-Gordillo J., Saiz-Jimenez C. Bacteria in the efflorescence of saint Jerome church, Granada, Spain. In: Protection and Conservation of the Cultural Heritage of the Mediterranean Cities. $5^{\text {th }}$ International Symposium on the Conservation of Monuments in the Mediterranean Basin. Seville, 2000, pp.15-16.

[11] Boquet E., Boronat A., Ramos-Cormenzana A. Production of calcite (calcium carbonate) crystals by soil bacteria is a general phenomenon. Nature; 1973, 246: 527-528.

[12] Katkova V.I., Rakin V.I. Bacterial genesis of calcite. Journal of Crystal Growth, 1994; $142(1-2): 271-274$.

[13] Carballal R., Paz-Bermúdez G., Sánchez-Biezma M.J., Prieto B. Lichen colonization of coastal churches in Galicia: biodeterioration implications. International Biodeterioration \& Biodegradation, 2001; 47:157-163.

[14] Silva B., Rivas T, Prieto B. Effects of lichens on the geochemical weathering of granitic rocks. Chemosphere, 1999; 39 (2): 379-388.

[15] Ascaso C., Wierzchos J., Delgado Rodriguez J. In situ studies of microorganisms biodeterioration action and direct evaluation of biocide effects. In: Protection and Conservation of the Cultural Heritage of the Mediterranean Cities. $5^{\text {th }}$ International Symposium on the Conservation of Monuments in the Mediterranean Basin. Seville, 2000, pp. 153-154. 
[16]López-Arce P, García-Guinea J, Fierro JLG. Manganese micro-nodules on ancient brick walls. Science of Total Environment, 2003; 302: 267-274.

[17]López-Arce P., García-Guinea J., Gracia M., Obis J. Bricks in historical buildings of Toledo City: characterisation and restoration. Materials Characterization, 2003; 50:59-68.

[18] Veniale F. Modern techniques of analysis applied to ancient ceramics. Advanced Workshop "Analytical Methodologies for the investigation of Damaged stones" Pavia (Italy) (1990).

[19] Rivadeneyra MA, Delgado G, Soriano M, Ramos-Cormenzana A, Delgado R. Biomineralization of Carbonates by Marinococcus albus and Marinococcu halophilus Isolated from the Salar de Atacama (Chile). Current Microbiology, 1999; 39: 53-57.

[20] Rivadeneyra MA, Ramos-Cormenzana A, Delgado G, Delgado R. Process of carbonate precipitation by Deleya halophila. Current Microbiology, 1996; 32:308-313.

[21] Rivadeneyra MA, Delgado G, Ramos-Cormenzana A, Delgado R. Biomineralization of carbonates by Halomonas eurihalina in solid and liquid media with different salinities: cristal formation sequence. Research Microbiology, 1998; 149:277-286.

[22] Ariño X., Gomez-Bolea A., Saiz-Jimenez C. Lichens on Ancient Mortars. International Biodeterioration \& Biodegradation, 1997; 40 (2 4):217-224.

[23] Tiano P., Biagiotti L., Mastromei G. Bacterial bio-mediated calcite precipitation for monumental stones conservation: methods of evaluation. Journal of Microbiological Methods, 1999; 36:139-145.

[24] Török A. Surface strength and mineralogy of weathering crust on limestone buildings in Budapest. Building and Environment, in press. 


\section{Fiqure Captions}

Figure 1. XRD patterns of the sampled bricks.

Figure 2. SEM images of physical and chemical weathering: fissures, corrosion, dissolution and re-crystallization processes. (A) Shrinkage - cracks on the surface of sample CG1; (B) Calcite crystal with corrosion pits surrounded by secondary calcite deposits on the surface of sample COR b; (C) Diluted calcite crystal in AL2; (D) Dissolution-corrosion-reprecipitation of calcite crystals inside AL3.

Figure 3. SEM images of biological weathering: organic deposits on brick surfaces and mineral bio-crystallization. (A) Fungal spores in sample COR; (B) bacterial colony covering the surface of AL3; (C) manganese micronodules under a biofilm on the surface of sample AL1; (D) calcite spherules divided into two parts on the surface of sample CG1.

Table 1. Appearance, parent building and construction period of the sampled bricks.

Table 2. Location and position in the parent buildings of brick samples exposed to aerial environments.

Table 3. Architectonic structures of brick samples exposed to burial environments.

Table 4. Mineralogical composition and physical properties of the brick samples.

Table 5. Compilation of the weathering traces in the sampled bricks.

Table 6. Physical properties of the sampled bricks.

Table 7. Firing temperatures, age and abundance of weathering traces: physical (cracks, fissures), physico-chemical (corrosion-dissolution-recrystallization) and biological (organisms and organic deposits). Numbers 1 to 3 indicate the presence of one (1), two (2) or three types of weathering (3). 


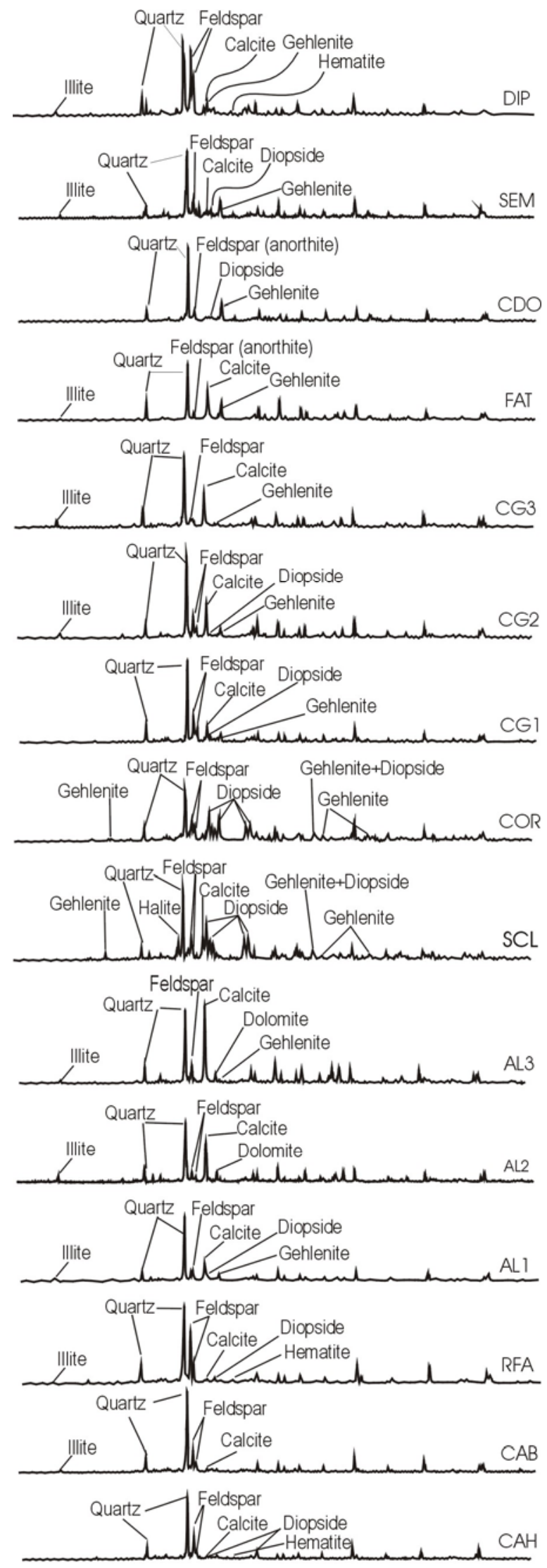

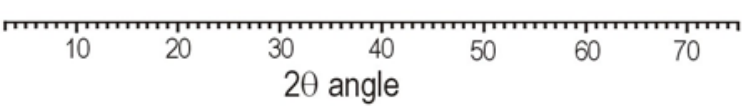

Figure 1

Lopez-Arce \& Garcia-Guinea 

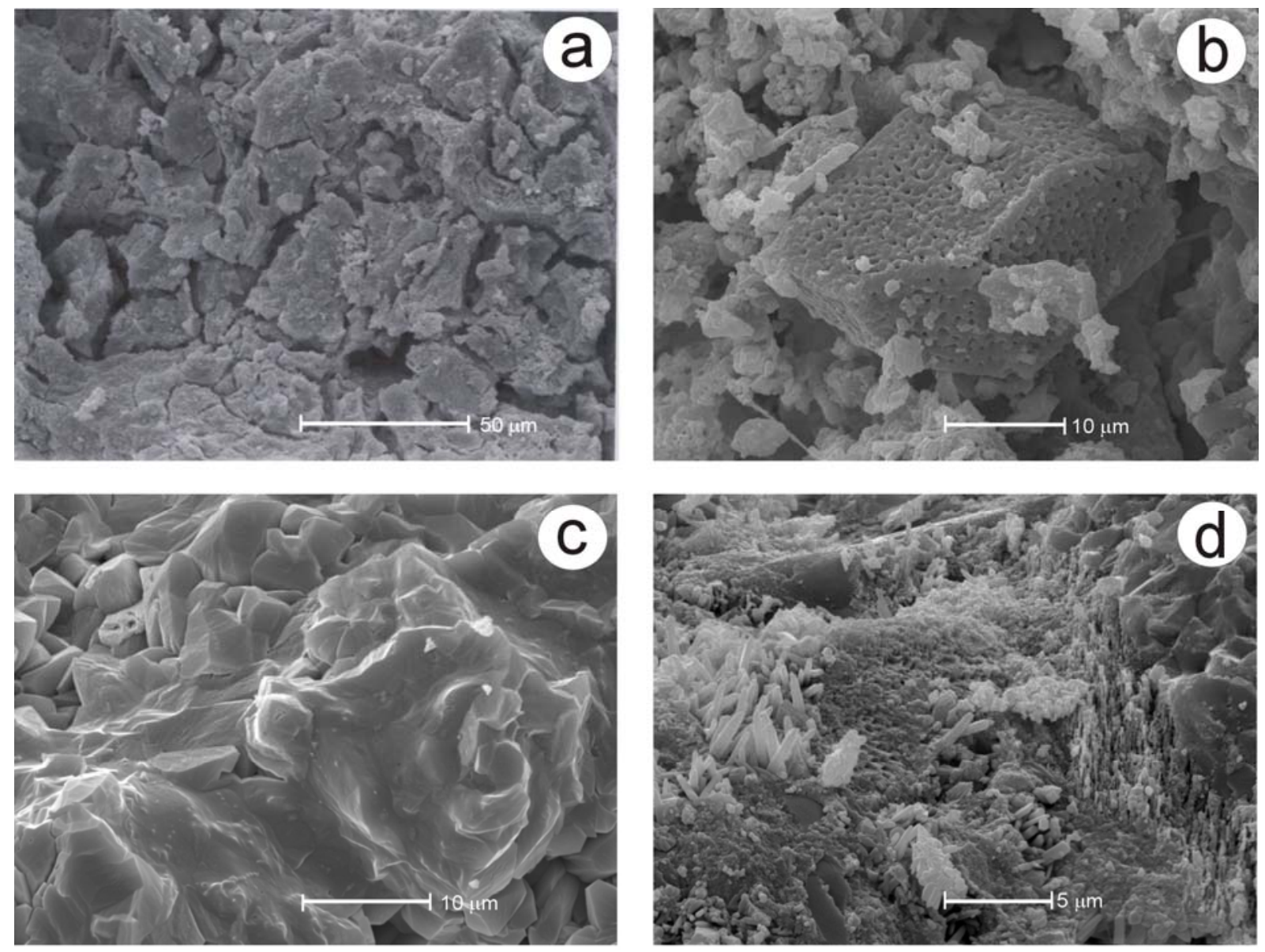

Figure 2

Lopez-Arce \& Garcia-Guinea 

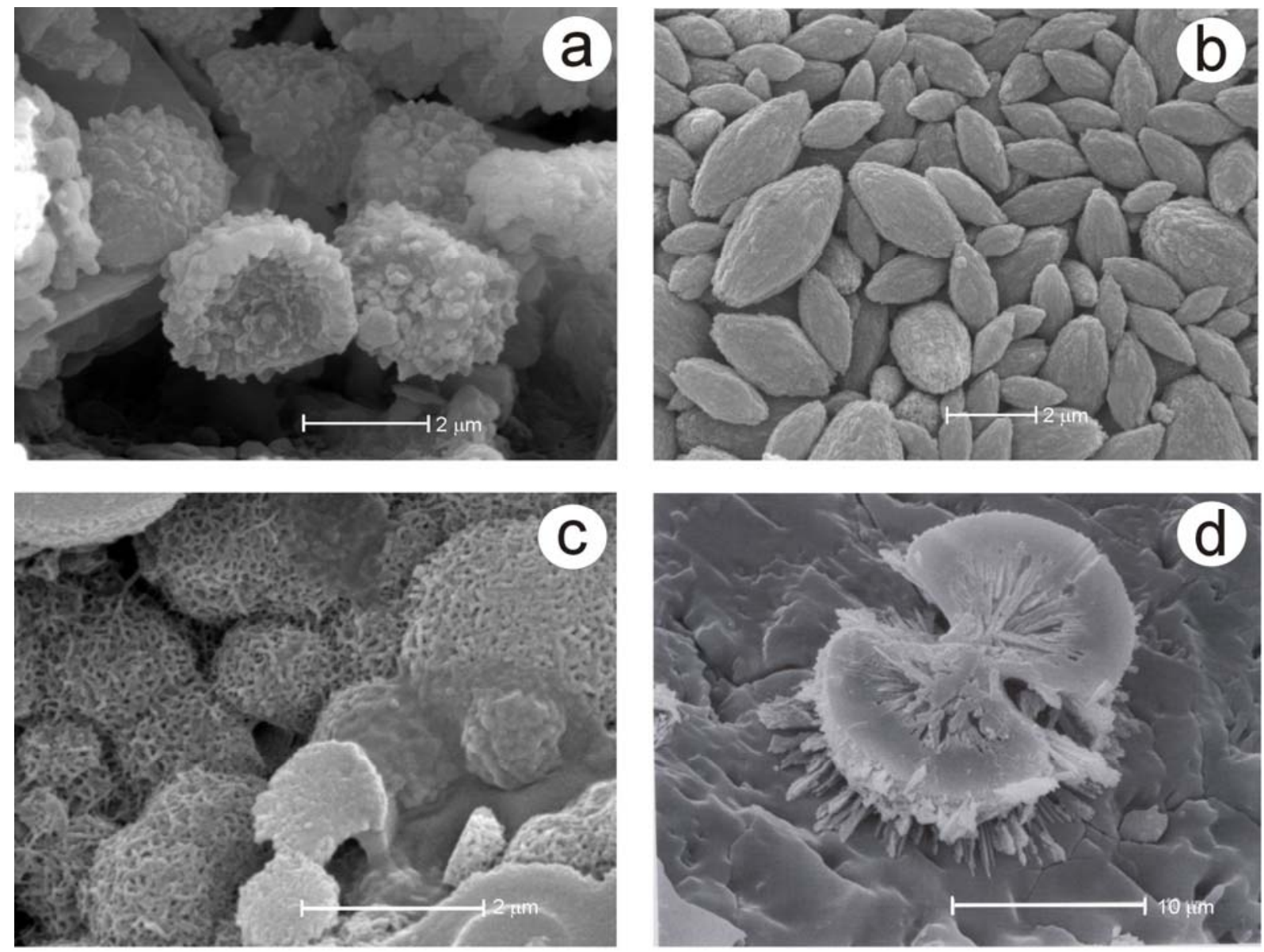

Figure 3

Lopez-Arce \& Garcia-Guinea 


\begin{tabular}{|c|c|c|c|c|c|}
\hline \multirow{2}{*}{$\begin{array}{c}\text { Brick } \\
\text { sample }\end{array}$} & \multicolumn{2}{|c|}{ Appearance } & \multirow{2}{*}{$\begin{array}{c}\text { Origin } \\
\text { (Historical Building) }\end{array}$} & \multirow{2}{*}{$\begin{array}{l}\text { Brick Age } \\
\text { (century) }\end{array}$} & \multirow{2}{*}{ Construction Period } \\
\hline & Colour & Texture & & & \\
\hline DIP & Light brown - light salmon pink & Many fine detrital grains. & $\begin{array}{l}\text { Palacio Diputación } \\
\text { Provincial }\end{array}$ & XIX & \multirow[b]{2}{*}{ Contemporary } \\
\hline SME & Orange reddish - pale pink & $\begin{array}{l}\text { Very coarse rock fragments and } \\
\text { grog. Many detrital grains of all } \\
\text { sizes. }\end{array}$ & $\begin{array}{l}\text { Seminario Mayor San } \\
\text { Ildefonso }\end{array}$ & XIX & \\
\hline CDO & Light salmon pink - creamy white & Scarce, fine detrital grains. & Colegio Doncellas Nobles & XVIII & \multirow[b]{2}{*}{ Neoclassical } \\
\hline FAT & Salmon pink - brownish orange & $\begin{array}{l}\text { Some coarse detrital grains and a } \\
\text { few medium and fine grains. }\end{array}$ & $\begin{array}{l}\text { Fábrica de Armas - } \\
\text { Palacio Sabatini }\end{array}$ & XVIII & \\
\hline CG3 & Light brown & Scarce, fine detrital grains. & \multirow{3}{*}{ Casa del Greco } & XIV-XV & Islamic-Mudejar \\
\hline CG2 & Salmon orange - pale reddish & $\begin{array}{l}\text { Some fine and medium size } \\
\text { grains. Crypto-efflorescences. }\end{array}$ & & XIII-XIV & Mudejar - Romanesque \\
\hline CG1 & Brown - salmon orange & A few, fine detrital grains. & & $\mathrm{X}-\mathrm{XII}$ & Islamic \\
\hline COR & Beige - creamy & $\begin{array}{l}\text { Fine-textured matrix with a lot of } \\
\text { grog and melted vitreous flows. }\end{array}$ & Corralillo San Miguel & XIII-XIV & Islamic-Mudejar \\
\hline SCL & Yellowish white - creamy & $\begin{array}{l}\text { Very fine-textured matrix with } \\
\text { very few detrital grains. }\end{array}$ & $\begin{array}{l}\text { Convento de San } \\
\text { Clemente }\end{array}$ & XIII-XIV & Mudejar - Romanesque \\
\hline AL3 & Salmon pink & $\begin{array}{l}\text { Fine-textured matrix with some } \\
\text { coarse detrital grains. }\end{array}$ & \multirow{3}{*}{ Alcázar de Toledo } & XII-XIII & \multirow[b]{2}{*}{ Mudejar - Romanesque } \\
\hline AL2 & Light brown - salmon orange & $\begin{array}{l}\text { Some fine detrital grains. Inner } \\
\text { pale brown band. Crypto- } \\
\text { efflorescences. }\end{array}$ & & XII-XIII & \\
\hline AL1 & Light salmon pink - creamy & $\begin{array}{l}\text { Some fine detrital grains. Many } \\
\text { black spots covering the surface. }\end{array}$ & & $\mathrm{X}$ & Islamic \\
\hline RFA & Orange - brown & $\begin{array}{l}\text { Many medium and fine detrital } \\
\text { grains. Black core. }\end{array}$ & Fábrica de Armas & III-IV & \multirow{3}{*}{ Roman } \\
\hline CAB & Orange & $\begin{array}{l}\text { Many coarse, medium and fine } \\
\text { detrital grains. }\end{array}$ & \multirow{2}{*}{$\begin{array}{c}\text { Fuente Cabrahigos } \\
\text { (Roman Baths) }\end{array}$} & \multirow[b]{2}{*}{ I-II } & \\
\hline САH & Dark red & $\begin{array}{l}\text { Many coarse, medium and fine } \\
\text { detrital grains. Strongly black } \\
\text { core. }\end{array}$ & & & \\
\hline
\end{tabular}

Table 1 


\section{TABLE 2}

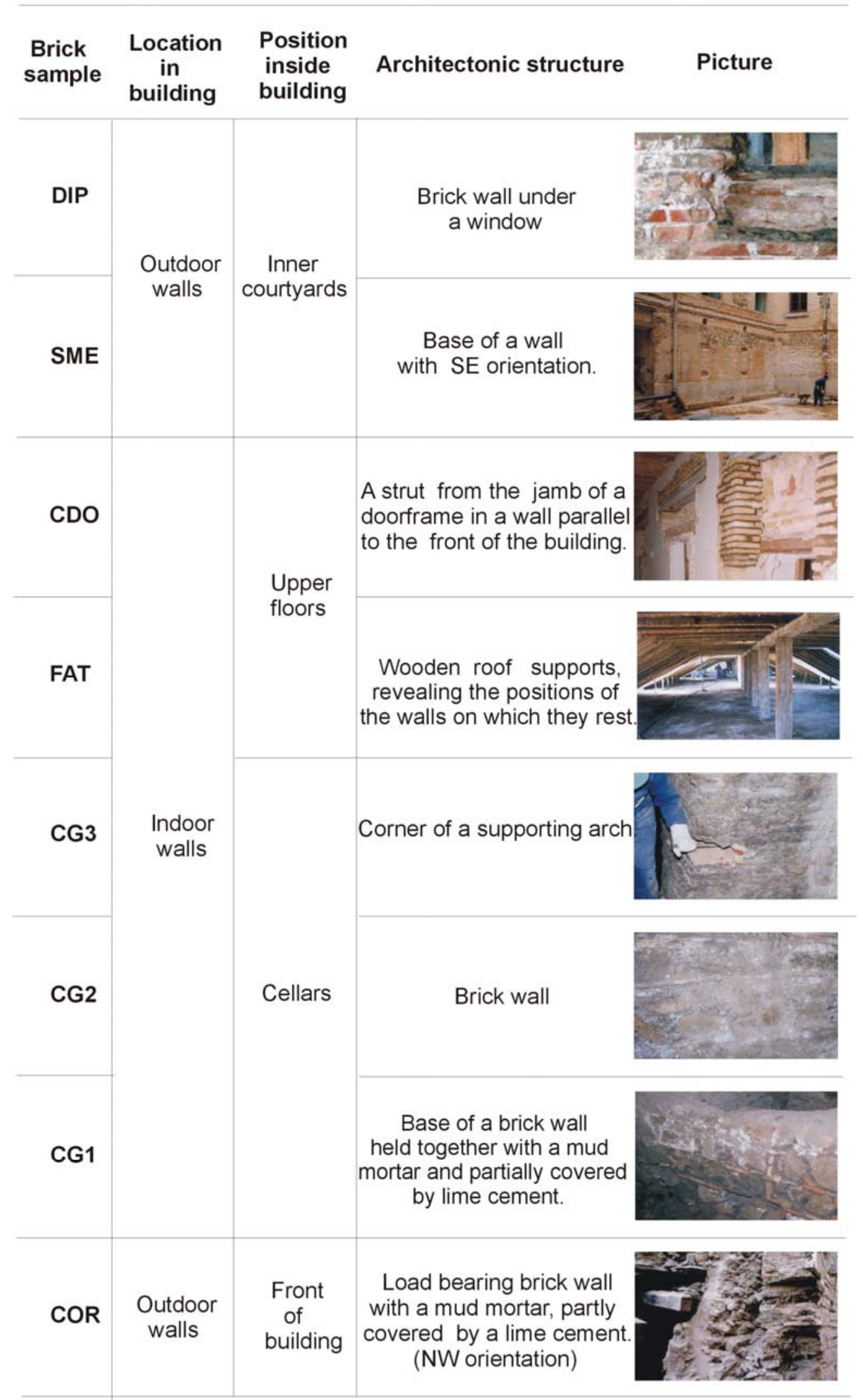




\section{TABLE 3}

\section{Brick sample}

\begin{tabular}{l|l|l|}
\hline SCL & $\begin{array}{l}\text { Wall buried under the cellar below the } \\
\text { sacristy of the San Clemente convent. } \\
\text { The circle marks a corner formed by } \\
\text { two walls. }\end{array}$ \\
\hline AL3 & $\begin{array}{l}\text { Top of a buried brick wall with lime } \\
\text { mortar. The wall belongs to an arche. }\end{array}$ \\
\hline AL2 & $\begin{array}{l}\text { Top of a buried brick wall with lime } \\
\text { mortar. The wall belongs to an arche. }\end{array}$ \\
\hline AL1 & $\begin{array}{l}\text { Top of a buried brick wall held } \\
\text { together with a mud mortar. } \\
\text { Base of a brick fountain. } \\
\text { (a relict of a Roman village) }\end{array}$ \\
\hline
\end{tabular}

CAB

Hot water conduit under a floor. (a structural relict)

\section{$\mathrm{CAH}$}

Pillar supporting the floor of a water-heated room. (a structural relict)

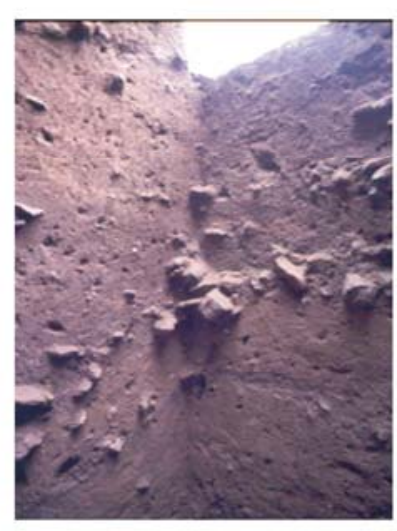


Table 4

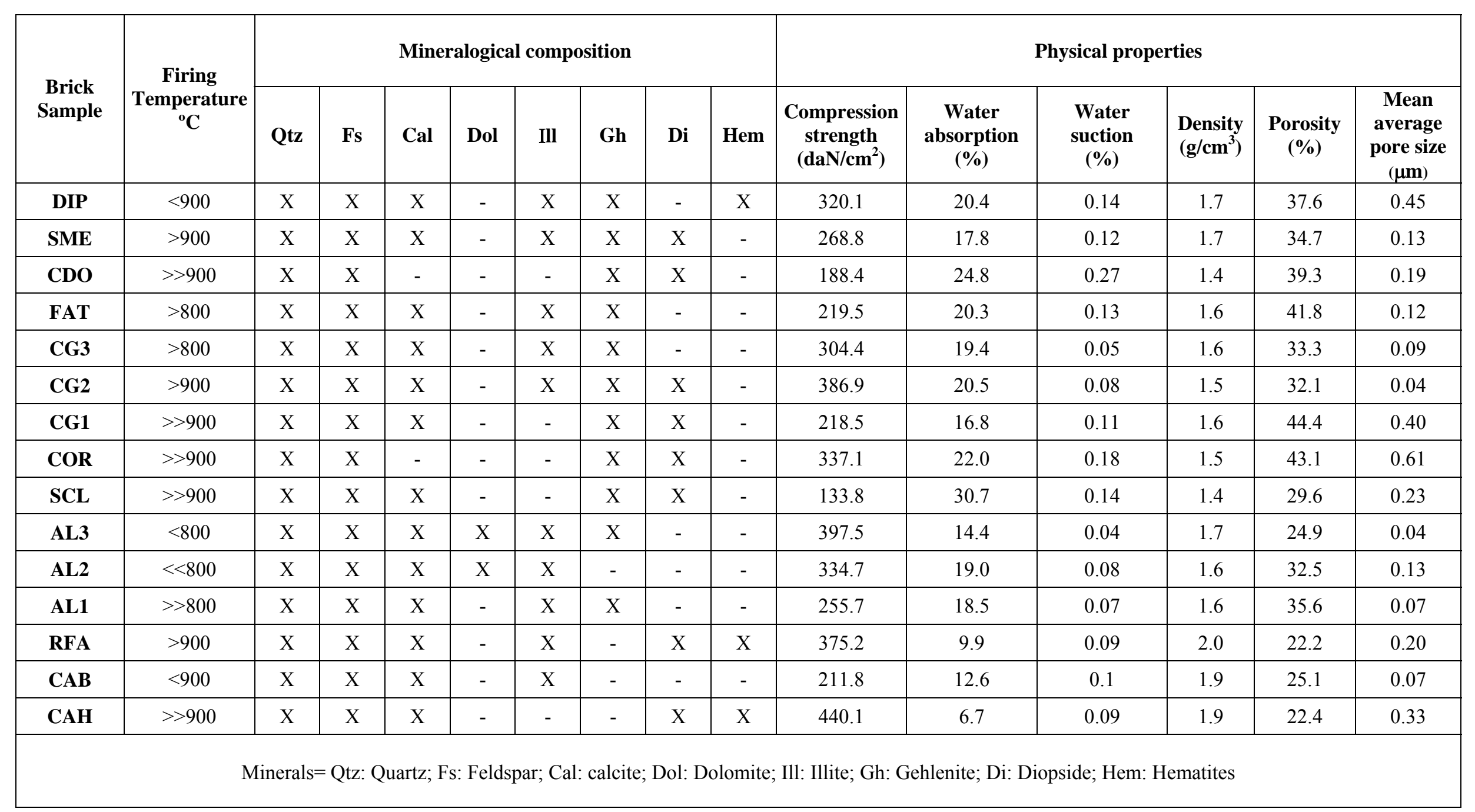


Table 5

\begin{tabular}{|c|c|c|c|c|c|c|c|c|}
\hline \multirow{3}{*}{$\begin{array}{l}\text { Brick } \\
\text { Sample }\end{array}$} & \multicolumn{5}{|c|}{ Physico-chemical Weathering } & \multicolumn{3}{|c|}{ Biological Weathering } \\
\hline & \multirow{2}{*}{$\begin{array}{l}\text { Fissures } \\
\text { and } \\
\text { Fractures }\end{array}$} & \multirow[b]{2}{*}{ Corrosion } & \multirow[b]{2}{*}{ Dissolution } & \multicolumn{2}{|c|}{ Re-crystallization } & \multirow[b]{2}{*}{ Organic deposits } & \multicolumn{2}{|c|}{ Re-crystallization } \\
\hline & & & & External surface & Inside sample & & External surface & Inside sample \\
\hline DIP & Absent & Scarce & Absent & Absent & Absent & $\begin{array}{l}\text { Abundant: fungi (hyphae } \\
\text { framework) }\end{array}$ & Absent & Absent \\
\hline SME & $\begin{array}{l}\text { Moderate: } \\
\text { fissures }\end{array}$ & Absent & Scarce & Absent & $\begin{array}{l}\text { Abundant: calcite piped } \\
\text { crystals and gypsum }\end{array}$ & $\begin{array}{l}\text { Scarce: fungi covering } \\
\text { crystals }\end{array}$ & Absent & Absent \\
\hline CDO & Absent & Absent & Absent & $\begin{array}{l}\text { Abundant: globular and } \\
\text { elongated calcite crystals }\end{array}$ & $\begin{array}{l}\text { Scarce: globular and } \\
\text { elongated calcite }\end{array}$ & $\begin{array}{l}\text { Moderate: fungi covering } \\
\text { crystals }\end{array}$ & Absent & Absent \\
\hline FAT & Absent & Absent & Moderate & Absent & Scarce: calcite & $\begin{array}{c}\text { Abundant: bacteria } \\
\text { (streptococcus), hyphae }\end{array}$ & $\begin{array}{c}\begin{array}{c}\text { Scarce: apatite micro- } \\
\text { nodules }\end{array} \\
\end{array}$ & Absent \\
\hline CG3 & Absent & Absent & Absent & Absent & $\begin{array}{c}\text { Moderate: } \\
\text { calcite and } \mathrm{SiO}_{2} \text { nodules }\end{array}$ & $\begin{array}{l}\text { Scarce: organic micro- } \\
\text { nodules, spores, hyphae }\end{array}$ & Absent & Absent \\
\hline CG2 & Absent & Scarce & Scarce & $\begin{array}{l}\text { Scarce gypsum } \\
\text { Moderate } \mathrm{NaCl}\end{array}$ & $\begin{array}{l}\text { Abundant: globular and } \\
\text { elongated calcite, } \mathrm{NaCl}\end{array}$ & $\begin{array}{l}\text { Abundant: fungi (hyphae } \\
\text { framework) }\end{array}$ & Absent & Absent \\
\hline CG1 & $\begin{array}{l}\text { Abundant: } \\
\text { cracks }\end{array}$ & Moderate & Abundant & Intense: $\mathrm{NaCl}$, calcite & $\begin{array}{c}\text { Moderate: } \\
\text { calcite and } \mathrm{NaCl}\end{array}$ & Absent & $\begin{array}{l}\text { Scarce: calcite } \\
\text { spherules }\end{array}$ & Absent \\
\hline COR & Absent & Moderate & Scarce & $\begin{array}{l}\text { Abundant: aragonite, } \\
\mathrm{NaCl} \text {, gypsum }\end{array}$ & Absent & $\begin{array}{l}\text { Abundant: fungi (hyphae } \\
\text { framework), spores }\end{array}$ & Absent & Absent \\
\hline SCL & $\begin{array}{l}\text { Intense: } \\
\text { fractures }\end{array}$ & Moderate & Scarce & Scarce: gypsum crusts & Scarce: calcite & Scarce: bacteria & Absent & $\begin{array}{l}\text { Scarce: isolated Fe- } \\
\text { Mn micronodules }\end{array}$ \\
\hline AL3 & Absent & Moderate & Abundant & Scarce: aragonite & $\begin{array}{c}\text { Abundant: calcite in pore } \\
\text { system }\end{array}$ & $\begin{array}{c}\text { Abundant: diatom, } \\
\text { bacteria colony, bio-films }\end{array}$ & Absent & Absent \\
\hline AL2 & $\begin{array}{l}\text { Abundant: } \\
\text { fissures }\end{array}$ & Moderate & Abundant & Scarce: calcite & $\begin{array}{l}\text { Abundant: calcite in } \\
\text { fissures and pores }\end{array}$ & $\begin{array}{l}\text { Moderate: spores, bio- } \\
\text { film }\end{array}$ & $\begin{array}{c}\text { Moderate: isolated Mn } \\
\text { micro-nodules }\end{array}$ & Absent \\
\hline AL1 & Absent & Moderate & Abundant & Scarce: calcite & Moderate: aragonite & $\begin{array}{l}\text { Intense: bio-film (lichen- } \\
\text { algae), bacteria }\end{array}$ & $\begin{array}{l}\text { Intense: manganese } \\
\text { micro-nodules }\end{array}$ & Absent \\
\hline RFA & Absent & Abundant & Scarce & Scarce: gypsum, calcite & $\begin{array}{l}\text { Scarce: micro-nodules Al- } \\
\text { Si-Fe }\end{array}$ & Absent & Absent & Absent \\
\hline CAB & Absent & Moderate & Moderate & Scarce: gypsum & Absent & Scarce: hyphae & Absent & Absent \\
\hline САH & Absent & Scarce & Absent & Scarce: quartz & Absent & Scarce: organic relicts & Absent & Absent \\
\hline
\end{tabular}


Table 6 and 7

\begin{tabular}{|l|c|c|}
\hline \multicolumn{1}{|c|}{ Water absorption } \\
\hline Very High & $\mathbf{( \% )}$ & samples \\
\hline High & $\geq 25$ & SCL, CDO \\
\hline Medium & $20-25$ & COR, CG2, DIP, FAT \\
\hline Low & $15-20$ & CG3, AL2, AL1, SME, CG1 \\
\hline Very low & $10-15$ & AL3, CAB \\
\hline \multicolumn{2}{|c|}{ Water suction } \\
\hline
\end{tabular}

\begin{tabular}{|l|c|c|}
\hline \multicolumn{1}{|c|}{ level } & $\mathbf{( \% )}$ & samples \\
\hline Very High & $>0.20$ & CDO \\
\hline High & $0.15-0.20$ & COR \\
\hline Medium & $0.10-0.15$ & DIP, SCL, FAT, SME, CG1, CAB \\
\hline Low & $0.05-0.10$ & CAH, RFA, AL2, CG2, AL1 \\
\hline Very low & $<0.05$ & AL3, CG3 \\
\hline \multicolumn{2}{|c|}{ Density } \\
\hline \multicolumn{2}{|c|}{} \\
\hline
\end{tabular}

\begin{tabular}{|l|c|c|}
\hline \multicolumn{1}{|c|}{ level } & $\mathbf{( g / \mathbf { c m } ^ { 3 } )}$ & samples \\
\hline Very High & $\geq 1.9$ & RFA, CAB, CAH \\
\hline High & $1.7-1.8$ & DIP, SME, AL3 \\
\hline Medium & 1.6 & FAT, CG3, CG1, AL2, AL1 \\
\hline Low & 1.5 & CG2, COR \\
\hline Very low & 1.4 & CDO, SCL \\
\hline \multicolumn{2}{|c|}{ Porosity }
\end{tabular}

\begin{tabular}{|l|c|c|}
\hline \multicolumn{1}{|c|}{ level } & $\mathbf{( \% )}$ & Porosity \\
\hline Very High & $>40$ & CGmples \\
\hline High & $35-40$ & CDO, DIP, AL1 \\
\hline Medium & $30-35$ & SME, CG3, AL2, CG2 \\
\hline Low & $25-30$ & SCL, CAB \\
\hline Very low & $20-25$ & AL3, CAH, RFA \\
\hline \multicolumn{2}{|c|}{}
\end{tabular}

\begin{tabular}{|c|c|c|}
\hline Very low & $20-25$ & AL3, CAH, RFA \\
\hline \multicolumn{3}{|c|}{ Mean diameter of pore } \\
\hline level & $(\mu \mathrm{m})$ & samples \\
\hline Very High & $>0.40$ & COR, DIP, CG1, \\
\hline High & $0.30-0.40$ & $\mathrm{CAH}$ \\
\hline Medium & $0.20-0.30$ & SCL, RFA \\
\hline Low & $0.10-0.20$ & CDO, SME, AL2, FAT \\
\hline \begin{tabular}{|l|} 
Very low \\
\end{tabular} & $<0.10$ & CG3, AL1, CAB, CG2, AL3 \\
\hline \multicolumn{3}{|c|}{ Compression strength } \\
\hline level & $\left(\mathrm{daN} / \mathrm{cm}^{2}\right)$ & samples \\
\hline \begin{tabular}{|l|} 
Very High \\
\end{tabular} & $>400$ & $\mathrm{CAH}$ \\
\hline High & $300-400$ & AL3, CG2, RFA, COR, AL2, DIP, CG3 \\
\hline Medium & $200-300$ & SME, AL1, FAT, CG1, CAB \\
\hline Low & $100-200$ & $\mathrm{CDO}, \mathrm{SCL}$ \\
\hline Very low & $<100$ & - \\
\hline
\end{tabular}

\begin{tabular}{|c|c|c|}
\hline \multicolumn{3}{|c|}{ Firing temperature } \\
\hline Grade & $\left({ }^{\circ} \mathrm{C}\right)$ & samples \\
\hline Very High & $>>900$ & CDO, CG1, COR, SCL, CAH \\
\hline High & $>900$ & SME, CG2, RFA \\
\hline Medium-High & $<900$ & DIP, CAB \\
\hline Medium-Low & $>800$ & FAT, CG3, AL1, \\
\hline Low & $<<800$ & AL2, AL3 \\
\hline \multicolumn{3}{|c|}{ Brick age } \\
\hline \multicolumn{2}{|c|}{ Century } & samples \\
\hline More recent & XVIII-XIX & DIP, SME, CDO, FAT \\
\hline \multirow{2}{*}{ Ancient } & XIII-XV & CG3, CG2, COR, SCL \\
\hline & X-XIII & AL3, AL2, CG1, AL1 \\
\hline Very ancient & $<\mathrm{X}$ & RFA, CAB, CAH \\
\hline \multicolumn{3}{|c|}{ Weathering traces } \\
\hline \multicolumn{2}{|c|}{ Abundance } & samples \\
\hline High & 3 & AL2, AL1, CG1, SCL, AL3, SME, COR \\
\hline Medium & 2 & CG2, FAT, RFA, CDO, CG3, CAB \\
\hline Low & 1 & DIP, $\mathrm{CAH}$ \\
\hline
\end{tabular}

